\title{
APPLICATION OF AUGMENTED REALITY TECHNOLOGY IN THE ANIMATION OF THE KANCIL CHILDREN'S STORYBOOK
}

\author{
Suhendra' ${ }^{1 *}$, Siti Aisyah ${ }^{2}$, Fathan Mubina Dewadi ${ }^{3}$ \\ Desain Grafis ${ }^{1}$, Teknik Grafika ${ }^{2}$ \\ Politeknik Negeri Media Kreatif 1,2 \\ https://polimedia.ac.id/ \\ suhendra030514@gmail.com, sitiaisyah@polimedia.ac.id \\ Teknik Mesin ${ }^{3}$ \\ Universitas Buana Perjuangan Karawang ${ }^{3}$ \\ http://ubpkarawang.ac.id \\ fathan.mubina@ubpkarawang.ac.id
}

\begin{abstract}
There are relatively many Indonesian fairy tales that are spread in the community, have characters with good and evil temperaments. Usually take folk tales about teaching goodness, behaving smartly, and being able to distinguish between good and bad. Also teaches children not to be arrogant, insulting other people. The learning process is usually in the delivery of material using only pictures, dolls, or videos that are commonly seen by children. Conventional media used for learning reduce children's enthusiasm. On this occasion, to answer the problem of media that is less attractive to children by using Augmented Reality (AR) because it can help visualize abstract concepts so that it can be used for understanding the image object and the structure of an object model. results of making applications using Augmented Reality, assessed from the aspects of cognitive, affective, psychomotor, technological, and the benefits of getting good interpretation results.
\end{abstract}

Keywords: Augmented Reality, Folklore, Si Kancil

\begin{abstract}
Abstrak
Dongeng Indonesia relatif banyak yang tersebar di masyarakat, memiliki karakter dengan perangai yang baik dan jahat. Biasanya mengabil cerita rakyat yang tentang mengajarkan kebaikan, berperilaku cerdik serta dapat membedakan mana yang baik dan mana yang buruk. Juga mengajarkan anak-anak tidak sombong, menghina orang lain. Proses pembelajaran biasanya dalam penyampaian materi hanya menggunakan gambar, boneka atau video yang sudah biasa dilihat oleh anak- anak. Media konvensional yang digunakan untuk belajar mengurangi antusias anak-anak. Dalam kesempatan ini untuk menjawab permasalahan media yang kurang menarik untuk anak-anak dengan menggunakan Augmented Reality (AR), karena bisa membantu memvisualisasikan konsep yang abstrak sehingga bisa untuk pemahaman mengenai objek gambar dan struktur suatu model objek. eHasil dari pembuatan aplikasi menggunakan Augmented Realty ini, dinilai dari aspek kognitif, Efektif, psikomotorik, teknologi, dan manfaat mendapatkan hasil interpretasi yang baik
\end{abstract}

Kata kunci: Augmented Reality, Cerita Rakyat, Si Kancil

\section{INTRODUCTION}

Fairy tale books have their uniqueness from other books, this book does not present actual information and facts but can reflect behavior that can be liked by the reader and has a meaning that is useful for life. Ignoring the truth of the stories contained in storybooks, it will be interesting, if it is known among adults and children. With a good character model, this fairy tale book is usually drawn in two dimensions on a sheet of paper. With the help of dimensional models on paper, current technology can display models in three dimensions on the $\mathrm{x}, \mathrm{y}$, and $\mathrm{z}$ axes. One of the technologies in augmented reality. Augmented reality is a technology that can combine the real world with the virtual world (Safrodin, Zikky, Ghozi, \& Wicaksono, 2020). This kind of merging makes it easy to combine 3D objects that capture video in real-time 
on the phone screen, in other words, like merging the real world with the virtual world.

Some of the problems faced include storybooks that still use paper media and prints of writing and pictures as media. The limited movement of readers is less able to imagine if the media is paper and printed text and images as media. Understanding by using only paper media and prints of paintings and drawings feels less attractive to children. How can readers be more active in expressing and imagining when reading or viewing pictures of a story?

Some of the literature on problems in learning, among others, according to Hidayat (Hidayat, 2014) said that so far the delivery of material has only used pictures, dolls, or videos that are commonly seen by children. The media used for learning reduces children's enthusiasm in paying attention (Suciliyana et al., 2020). Combining augmented reality with cellphone vision, digitizing the fairy tale book will be more interesting because the book can interact with bare hands. The mobile vision that uses the principle of digital image processing will of course be very involved with color (Putra, 2013), while the color will be very closely related to light. This is because cellphone vision and augmented reality use a camera to capture images to be processed. Lifting the image with a sufficient light environment will produce colors with high contrast (clear color differences). Therefore the environment will be very influential with the course of this system.

This research conducted by Saurina (Saurina, 2016) invites the children of KBIT Wildani 2 Surabaya as respondents to the results of the application trial that has been built. The results of the trial explained that $93 \%$ of children could recognize animal objects from their environment, $100 \%$ said that children could repeat the spelling of the names of animals in Indonesian using augmented reality, $95 \%$ of children could repeat the spelling of names of animals in English which demonstrated with augmented reality, 95\% of children can mention the characteristics of animals by choosing one of the body parts of the selected animal, and $100 \%$ stated that children are more interested in using AR than using Educational Teaching Aids (APE) as learning media (Bernard \& Alam, 2020).

Novan \& Risya, stated that the results of the analysis of data acquisition required educational media in the form of augmented reality (AR) based historical storybooks (Novan \& Risya, 2016). Research by choosing AR media is motivated by the growing use of digital media in the world as a means of education. His research uses digital media as a means of education. The results of this research and design resulted in the historical story of Ciung Wanara being more interactive and also based on Augmented Reality (AR).

Derived from color and light, the author tries to present the principle of digital imagery in terms of light where light is very influential in digital image processing. By paying special attention to the direction of light, the author hopes that through this, good lighting can be found in the operation of designing children's storybooks using Augmented Reality to make them look more interesting and alive.

\section{RESEARCH METHODS}

Making the application program conducted interviews with storybook readers such as children's playground teachers and children who enjoy storybooks about stories or fairy tales with Augmented Reality technology. Questionnaires were given to 20 newsbook connoisseurs and children's book news anchors with an age range of 10 to 25 years in the AR Kindergarten community. The Augmented reality had restricted utilization in the beginning phases of its creation in the clinical, promoting, and industry fields until it was utilized in the instruction field (Aldalalah, Waleed Mohamed Ababneh, Khaled Bawaneh, \& Mohammad Mahmoud Alzubi, 2019). Augmented reality is a method dependent on the innovation of moving the verifiable outer climate into advanced gadgets and afterward handling it carefully by adding a few impacts to it and afterward creating it through computerized screens (Aqel \& Abed Azzam, 2018; Azuma, 1997)

Cyclomatic Complexity (quantitative measurement of the logical complexity of a program) of a flow graph can be obtained by calculating.

$V(G)=E-N+2$

Information:

$E=$ Number of edges of the flow chart marked with arrows

$\mathrm{N}=$ Number of vertices of the flow chart marked with a circle

\section{RESULTS AND DISCUSSION}

\section{A. Requirement Analysis}

The software has different system or device requirements to function properly without any program errors caused by the system's incompatibility with the program being used. 


\section{B. Design}

The author designed a children's storybook animation program with augmented reality technology which is expected to make the audience more appreciate the storyline and feel like being in the story and feel the story being told, and of course, making the story feel better and more beautiful.

\section{Software Characteristics}

In designing a system, in this case, the design of the children's storybook animation program must be guided by the characteristics and elements contained in the storybook, namely:

\section{a. Format}

Connoisseurs will be made to feel they are in a small town full of scattered garbage. Viewers can freely rotate their eyes with a radius of $120^{\circ}$ vertically and horizontally to see the atmosphere and conditions presented in the story.

b. Rules

This story consists of Augmented reality. Within 2 minutes 12 seconds, the reader must use the camera to scan the marker so that the illustrated story of the mouse deer can be seen in 3D. Besides Si Kancil, there are also other ornaments such as Buildings or Shophouses where Humans do business which in the environment is filled with scattered garbage. Seeing this condition, Mouse Deer as a figure who is idolized by children does not stay silent and meets someone to tell him that it is not good and urges to be able to clean it again. The time will be counted down. During this period, the reader must enjoy the illustrated story and store the moral value in the story, which moral value is good if it is instilled in children aged under five or older, through the storyline of Si Kancil, the audience can take moral messages that will be embedded in their souls and embedded in them. later in real life, the child or the audience of the story can apply the good things that humans should be able to do as social beings and live in society.

c. Policy

The reader must scan the marker through the camera that has been adjusted as the story medium to be able to display the illustrated story and enjoy the results of the three-dimensional (3D) image.

d. Scenario

The first time the reader has to click the Story button to start the story. Then the reader will enter the story area. The reader will wait until he sees the mouse deer walking to look for a father who wants to be informed by him. From a small town that is littered with garbage, the mouse deer walks to meet someone to tell him to throw the garbage in its place, and after the mouse deer meets someone who is walking towards him, the mouse deer reprimanded the person and there was a dialogue between the mouse deer and someone who was walking around the city full of garbage. In the dialogue, the mouse deer called for the trash to be thrown in its place.

\section{e. Events/Challenge}

The challenge for children's book designers using augmented reality is how to make a story that is very popular with children where the characters are a superhero, animals, or the family environment so that children can enjoy the story where the child who reads the story will like it and the moral message will be to the fans of storybooks, the readers are toddlers who are easily bored and like to explore new things.

f. Roles

Connoisseurs of designing this children's storybook are better guided on how to read it, so they can start, and direct the story using a scan marker that is presented so that a story can be threaded that can be understood by the audience of the storybook using augmented reality.

g. Communication

So that the Sikanci story can be conveyed to these children, a visual communication approach is carried out, namely illustrating the Sikancil story using illustrations using visual elements of good behavior culture, using a culture of good behavior will be useful for the soul of children who will come. h. Verbal

In the verbal communication approach, formal but simple Indonesian will be used. The dialogue will be used how to communicate as in everyday life. The choice of simple language is intended to make it easier for children to understand a story that is conveyed.

i. Strategy Creative

The story strategy is made as interesting as possible to give the impression of curiosity in children who are enjoying the story so that they get a high desire or curiosity in children to complete the storyline presented.

j. Strategy Media

Media that can create the impression of space or depth such as Creative Strategy is to use augmented reality.

k. Symbols

There is a "start" button to start playing, an "information" button to get information, and biodata.

\section{StoryBoard Design}

\section{a. Storyboard menu opening}

The following is an overview of the storyboard of this application: A. Story Board menu opening. 
The following is an overview of the storyboard menu opening as described in the Figure1 below:

\begin{tabular}{|c|c|c|}
\hline Visual & Sketch & \multicolumn{1}{|c|}{ Audio } \\
\hline $\begin{array}{c}\text { On the opening } \\
\text { screen is the title of } \\
\text { the story. }\end{array}$ & & \\
\cline { 2 - 3 } & & \\
& & \\
& & \\
& & \\
& & \\
& & \\
& & \\
& & \\
\end{tabular}

Figure 1 Story Board Opening

b. Storyboard main menu

The following is an overview of the main menu storyboard as described in Figure 2 below:

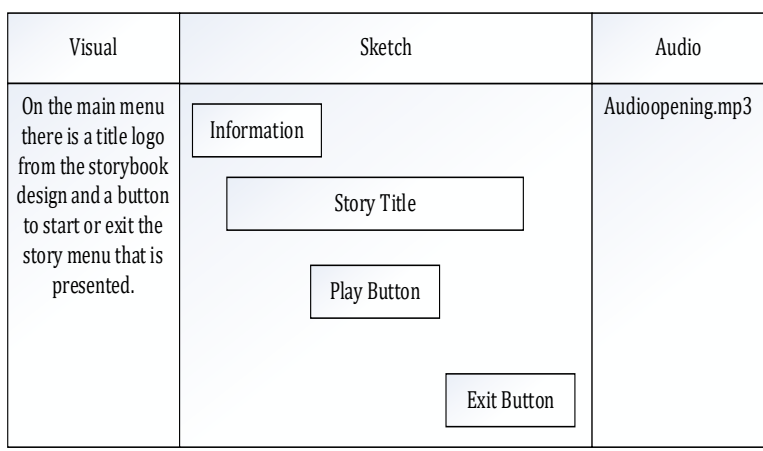

Figure 2. Main Menu

c. Storyboard View Children's Storybook Design

The following is an overview of the storyboard view of the story as described in Figure 3 below:

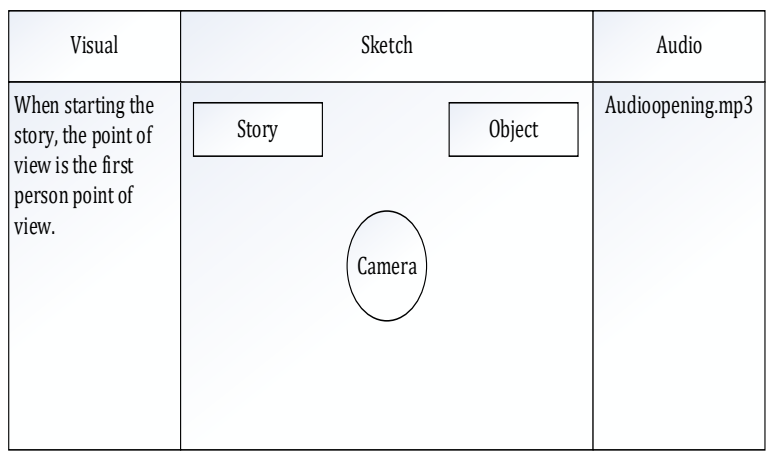

Figure 3. Storyboard View Children's Storybook Design

\section{User Interface Design}

After designing the storyboard, the next stage is designing the user interface. Where this stage is very important in the creation of interactive animation. The author uses a 3D model of the mouse deer as a game object. Display the user interface of
The design of this children's storybook is shown in Figure 4 as follows:

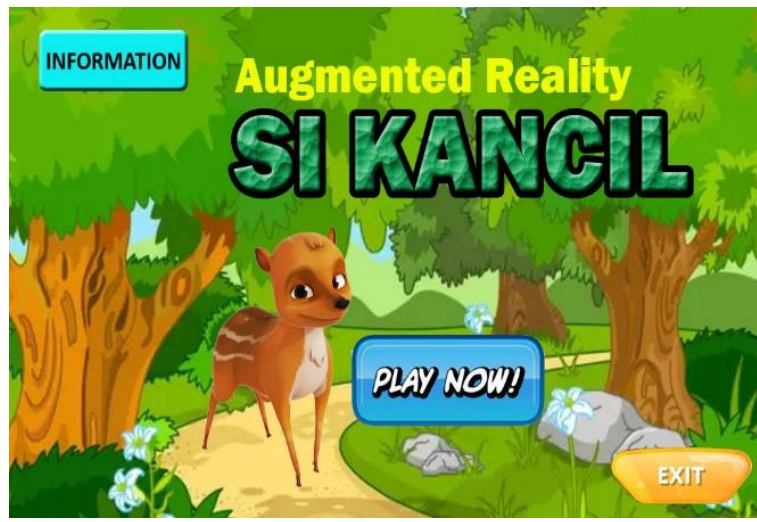

Figure 4. Main Menu

\section{Testing}

The program that has been made can be run well at the time of implementation by the user without any errors in terms of programming, it is necessary to have a test on the program system and file testing.

\section{a. White Box Testing}

It is a test case that uses a procedural design control structure to obtain a test case. By using the white box testing method, system engineers can perform test cases that can:

1. Assures that all independent paths in a module have been used at least once.

2. Using all logical decisions on the true and false sides.

3. Execute all loops at their limit.

4. Application user operations

In this case, a sample test was conducted on the first edition. Broadly speaking, the algorithm in this first edition is as follows:

1. Readers are only allowed to scan markers via Camera Mobile.

2. If the marker scan camera will produce a $3 d$ animation story on an ongoing basis.

3. If the scan marker is measured horizontally against the camera, the story will also become illegible or the story image will not appear.

4. If the countdown timer is up, the story ends. Below is Figure 7 of the storyline of the Si Kancil. 


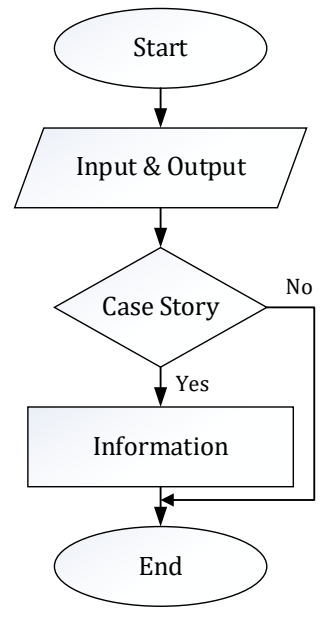

Figure 7. Storyline Diagram

So the cyclomatic complexity

$\mathrm{V}(\mathrm{G})=5-5+2=2$

The basis set resulting from linearly independent paths is the following path:

$1-2-3-4-5$

$1-2-3-5$

When the application is run, it is seen that the resulting base set is $1-2-3-4-5$ and it is seen that the node has been executed once.

Based on the observation of these provisions in terms of the feasibility of this system software has met the requirements.

\section{b. Black Box Testing}

Subsequent testing is carried out to ensure that an event or input will run the right process and produce output according to the design.

Table 1. Black Box Testing Process

\begin{tabular}{|c|c|c|c|}
\hline $\begin{array}{l}\text { Input/ } \\
\text { Event }\end{array}$ & Process & $\begin{array}{l}\text { Output/ } \\
\text { Next Stage }\end{array}$ & Test result \\
\hline
\end{tabular}

\begin{tabular}{llll}
\hline $\begin{array}{c}\text { "Start" } \\
\text { button }\end{array}$ & public void & Start & Accordance \\
The & public void Quit(0 & Exit & Accordance \\
"Exit" & & Program & \\
button & & & \\
\hline
\end{tabular}

Table 1 shows the black box testing process, with two-button tests, where the button is operated according to the desired results

\section{Interactive Animation Questionnaire Data Processing Results}

After knowing the value of the variable from all aspects, then look for the scale range to find out the interpretation of each variable with the following formula 2:

$R S=\frac{m-n}{b}$

Description:

$\mathrm{m}=$ the highest score in the measurement, the highest score is 4

$\mathrm{n}=$ the lowest score in the measurement, the lowest score is 1

$\mathrm{b}=$ the number of classes formed according to the answer choices, there are four classes (STS, TS, S, SS)

Then the scale range can be calculated as follows:

$R S=\frac{4-1}{4}=0,75$

With a scale range of 0.75 , the scale for interpretation is as follows:

Strongly Disagree : 1 to $1+0.75=1<\mathrm{x} 1.75$

Disagree : 1.75 to $1.75+0.75=1.75 \times 2.5$

Agree: 2.5 to $2.5+0.75=2.5 \times 3.25$

Strongly Agree : 3.25 to $3.25+0.75=3.25 \times 4$

The results of the assessment can be seen in table 2

Table 2. Interpretation Results

\begin{tabular}{|c|c|c|c|c|c|}
\hline No & Aspect & Description & Var Value 1,2 & Var & Interpretation \\
\hline \multirow[t]{2}{*}{1} & \multirow[t]{2}{*}{ Kognitif } & $\begin{array}{l}\text { After enjoying designing children's } \\
\text { storybooks, do you understand how to enjoy } \\
\text { this story? }\end{array}$ & 3,35 & \multirow[t]{2}{*}{3,5} & \multirow[t]{2}{*}{ Strongly agree } \\
\hline & & Is this story easy to understand? & 3,7 & & \\
\hline \multirow[t]{2}{*}{2} & \multirow[t]{2}{*}{ Afektif } & $\begin{array}{l}\text { Do you feel tired reading the design of this } \\
\text { storybook? }\end{array}$ & 2,15 & \multirow[t]{2}{*}{2,9} & \multirow[t]{2}{*}{ Agree } \\
\hline & & $\begin{array}{l}\text { Is the story presented is good and } \\
\text { interesting? }\end{array}$ & 3,65 & & \\
\hline \multirow[t]{2}{*}{3} & \multirow[t]{2}{*}{ Psychomotor } & Are the movements in this story easy to see? & 3,1 & \multirow[t]{2}{*}{3,23} & \multirow[t]{2}{*}{ Agree } \\
\hline & & Is it easy to use the click-on story option? & 3,35 & & \\
\hline \multirow[t]{2}{*}{4} & \multirow[t]{2}{*}{ Technology } & $\begin{array}{l}\text { Is this story suitable for use on } \\
\text { smartphones? }\end{array}$ & 3,6 & \multirow[t]{2}{*}{3,4} & \multirow[t]{2}{*}{ Strongly agree } \\
\hline & & $\begin{array}{l}\text { Is this story suitable to be played using } \\
\text { Augmented Reality? }\end{array}$ & 3,2 & & \\
\hline \multirow[t]{2}{*}{5} & \multirow[t]{2}{*}{ Benefit } & $\begin{array}{l}\text { Do you feel the experience of reading a } \\
\text { different story? }\end{array}$ & 3,75 & \multirow[t]{2}{*}{3,65} & \multirow[t]{2}{*}{ Strongly agree } \\
\hline & & Was this story fun to follow? & 3,55 & & \\
\hline
\end{tabular}




\section{CONCLUSION}

The whole application design uses Augmented Reality where users can enjoy designing children's storybooks and can be easily understood and enjoy the story of the Mouse Deer. The presentation of this story that is made is good and interesting. The buttons are also easy to use and users can experience a different and fun to follow.

\section{REFERENCES}

Aldalalah, O., Waleed Mohamed Ababneh, Z., Khaled Bawaneh, A., \& Mohammad Mahmoud Alzubi, W. (2019). Effect of Augmented Reality and Simulation on the Achievement of Mathematics and Visual Thinking Among Students. International Journal of Emerging Technologies in Learning (IJET), 14(18), 164185. https://doi.org/10.3991/IJET.V14I18.10748

Aqel, M. S., \& Abed Azzam, S. S. (2018). Effectiveness of Employing the Augmented Reality Technology in the Development of the Achievement of Seventh Grade Students in Chemistry in the Gaza Strip. International Journal of Learning Management Systems, 6(1), 27-42.

https://doi.org/10.18576/IJLMS/060103

Azuma, R. T. (1997). A Survey of Augmented Reality. Presence: Teleoperators and Virtual Environments, 6(4), 355-385. https://doi.org/10.1162/PRES.1997.6.4.355

Bernard, M., \& Alam, S. K. (2020). Improving English for early childhood through mathematical learning media VBA-assisted excel game. Journal of Physics: Conference Series, 1657(1), 012045. https://doi.org/10.1088/17426596/1657/1/012045

Hidayat, T. (2014). Penerapan Teknologi Augmented Reality Sebagai Model Media Edukasi Kesehatan Gigi Bagi Anak. Creative Information Technology Journal, 2(1), 77-92. https://doi.org/10.24076/CITEC.2014V2I1.3 9

Novan, R., \& Risya, A. (2016). Perancangan Buku Cerita Sejarah Ciung Wanara Berbasis Augmented Reality Untuk Anak Sekolah Dasar. Demandia: Jurnal Desain Komunikasi Visual, Manajemen Desain, Dan Periklanan, 1(2), 97-115. https://doi.org/10.25124/DEMANDIA.V1I02. 275

Putra, E. P. (2013). Pemodelan Buku Dongeng Digital Menggunakan Augmented Reality. Universitas Kristen Duta Wacana.
Safrodin, M., Zikky, M., Ghozi, S., \& Wicaksono, M. E. (2020). The 3D virtual drawing mobile application based on augmented reality using AR-Framework. Journal of Physics: Conference Series, 1450(1), 012078. https://doi.org/10.1088/17426596/1450/1/012078

Saurina, N. (2016). Pengembangan Media Pembelajaran Untuk Anak Usia Dini Menggunakan Augmented Reality. Jurnal IPTEK, 20(1), 95-108. https://doi.org/10.31284/J.IPTEK.2016.V20I 1.27

Suciliyana, Y., Ode Abdul Rahman, L., Komunitas, K., Ilmu Keperawatan Universitas Indonesia, F., Dasar Keperawatan dan Keperawatan Dasar, D., \& Ilmu Keperawatan, F. (2020). Augmented Reality Sebagai Media Pendidikan Kesehatan Untuk Anak Usia Sekolah. Jurnal Surya Muda, 2(1), 39-53. https://doi.org/10.38102/JSM.V2I1.51 